\title{
The Analysis of Factors Affect Timeliness Financial Statement of Indonesia Stock Exchange Company
}

\author{
S Suginam $^{1}$, R Rohminatin ${ }^{2}$, Hastuti Olivia ${ }^{3}$, Anda Yanny $^{1}$ \\ \{s.suginam@gmail.com\} \\ ${ }^{1}$ Department Of Computer Science, STMIK Budi Darma, North Sumatera, Indonesia
${ }^{2}$ Department Of Computer Science, STMIK ROYAL Kisaran, North Sumatera, Indonesia
Department Of Syari'ah Accounting, STAI Al Islahiyah Binjai, North Sumatera, Indonesia
}

\begin{abstract}
The process of submitting annual periodic financial statements shall have an opinion in accordance with or inappropriateness of such financial statements. Timely delivery of reporting will result in a good relevance to the reporting contents made to the decision maker, in this case, the investor. Many factor factors become the main obstacle in influencing timeliness in financial reporting of a company. In this research, researcher use several variables, that is variable of timeliness as the dependent variable, and company size variable, a variable of public accountant office as the independent variable. Researchers use a population of companies listed on the Indonesia Stock Exchange (BEI). The results of this study are expected to reveal the factors that become obstacles to timeliness of financial statement.
\end{abstract}

Keywords: Timeliness, Financial Statement

\section{Introduction}

The credibility of a company can be seen from reporting to its financial reporting. The regulation on this is done by the Capital Market Supervisory Agency (BAPEPAM) whereby every company with a Go Public status is required to submit its financial statements in accordance with the Financial Accounting Standards (SAK), and the financial statements have been audited by a public accountant registered with BAPEPAM. The financial statements are made useful for conveying information and describing the performance of the company's management in managing the company's resources. This has also been regulated in the Indonesian republican law no 8 of 1995 , concerning the capital market is clearly explained in the obligation to convey and announce a report which contains periodical information on business activities and the public company's financial condition for the effectiveness of supervision by BAPEPAM and the availability of information for the community and investors.

In the submission of a periodic financial reporting, the annual financial statements of the company shall be accompanied by a report from the accountant containing the usual opinion and the report shall be submitted at the end of the third month after the date of the annual financial statements. In the presentation of financial information has a normative measure, which is called the qualitative characteristics of relevant and reliable financial statements. But the main problem that is often encountered by the company, namely there are substantial constraints. One of the obstacles encountered is the timeliness in the delivery of financial 
statement. Timeliness in the delivery of corporate financial statements is one of the qualitative characteristics and this raises the benefits of the financial statements. If the delay occurs in the process of presenting the financial statements, the information expected from the financial statements will lose its relevance. Because timely information can be said to have a good relevance to the decision making, but relevance can not necessarily mean that the information owned by a financial statement, as expected by the decision maker.

Financial reports are presented in a timely manner, and can accurately produce information that is very useful and useful for users of financial statements. Timeliness in presenting the financial statements to the public is needed by investors, therefore it is expected not to delay in presenting the financial statements so that financial information can provide information relevant to the user let alone the company has gone public. If the financial statements are published in a timely manner, it will give a negative signal to the investors of the company and the company, in this case, will be subject to sanctions in the form of administrative sanctions, and penalties. For companies that are not on time, the capital market will consider such financial reporting, as a violation of the principle of information disclosure on the capital market. Therefore, the delivery of financial statements can be published in a timely manner. The time difference between the financial reporting date and the date of the audit opinion in the financial statements will indicate the length of time an audit completes an auditor. This time difference can be termed audit delay.

Many factors can affect the timeliness in the delivery of financial statements, including internal and external factors. In internal factors, timeliness is strongly influenced by firm size, profitability, solvency, internal auditors. As for external factors such as in this case the size of the public accounting firm, together have a very significant influence both on timeliness financial reporting.

Zooana Farida Panjaitan in 2013 conducted research on the factors that can affect audit delay and timeliness to the delivery of financial statements. The results revealed that the level of profitability is very influential on audit delay and timeliness in addition to other factors such as asset turnover [1]. Luanda Satya Pratama (2014) conducted research on the influence of internal and external factors on a company to variable timeliness financial statements. In his research shows the profitability variable and the size of public accountant office has a significant positive influence on timeliness in the delivery of financial statements [2].

By 2016, Sella Rachmawi covers research on factors affecting the timeliness of local government financial reporting in Indonesia. Based on the logistic regression test, it is indicated that the factors of regional independence, regional location, audit opinion and local government audit findings influence the timeliness of local financial reporting in Indonesia [3]. In this research, the researcher uses timeliness variable as the dependent variable, and firm size variable, public accountant variable as the independent variable[4]. The population data that researchers use is the population of companies listed on the BEI. The results of the research are expected to reveal whether the factors that become obstacles to a timeliness of financial statement have a big effect on the timeliness of corporate financial reporting.

Maslina Ahmad (2016) conducted a study to examine the linkages between industry specialist auditors with timeliness in conducting financial reporting according to the standards of Malaysian Financial Reporting Standards (MFRS)[5]. Bengū Vuran in 2013 conducted a study to analyze the relevance of accounting variables to the timeliness of financial reporting and the results of his research a number of variables such as total equity/total assets, ROE, ROA, and Cash flow are very influential[6]. 


\section{Theory}

\subsection{Financial Statements}

Financial Statements produced by the financial part of a company is the main means, wherein financial reporting there is financial information where outsiders can know clearly. These financial statements can provide a quantitative history of the firm in units of money [7]. Financial statements as an information will be very useful if the financial statements are presented in a timely manner so that the information contained will be useful for decision makers before the information loses its ability to influence decision making [8]. Timely financial reporting processes have the benefit of having management ensuring all processes are well underway, reference in making financial planning in the coming period, and informing investors about the company's financial condition.

\subsection{Audit Report}

The audit report is a media used by the auditor in communicating with the community within the company environment. As a result of audit reporting, the auditor may express his opinion on the fairness of the audited financial statements. Auditor's opinion on an audit report is presented in a written report, known as the standard audit report. The contents contained in the standard audit report consist of three (3) main paragraphs, the first paragraph contains the introductory paragraph, the second paragraph contains the scope paragraph, and the last paragraph of the paragraph contains the opinion (opinion paragraph).

\subsection{Timeliness}

Timeliness is a way of measuring transparency and the quality of financial reporting. Timely can also be interpreted as information that must be submitted as early as possible to avoid delayed decision-making related to the economy of a company [9]. However, timeliness does not guarantee the information provided in accordance with those received by users of financial statements. Timeliness is a very important indicator of the presentation of a relevant information and should have a predictive value[4].

\subsection{Report Lag}

The audit report lag is a period of time between the end of the fiscal year and the date of the audit report [9]. The result of measurement from the audit report variable lag is done quantitatively from the number of days between the end of the fiscal year to the date of issuance of the independent report from the auditor.

\subsection{Slovin Method}

One method used to determine the number of samples is to use the Slovin method [10], as follows:

$\mathrm{n}=\frac{\mathrm{n}}{1+\mathrm{ne}^{2}}$ 
Where $\mathrm{n}:$ Number of Samples

$\mathrm{N}$ : Number of Populations

e : error tolerance

\subsection{Operational Variable}

\subsubsection{Dependent Variable}

In the variable Dependent used, namely Timeliness (Y). Measurements for timelines are performed with the length of days required to obtain an independent auditor's financial report on the audit of the company's financial statements since the closing of the company's book, as of December 31, to the date set forth in the independent auditor's report.

\subsubsection{Dependent Variable}

For Independent variable used is company size (X1). The size of a company can be seen from how much the company has some information about itself (the complexity of operations and the intensity of the company's transactions) so that it will be more highlighted by the public than small companies. Can be measured by the total asset logarithm (Asset). The second independent variable used, ie the size of the public accounting firm (X2). The size of a public accounting firm (KAP) is an institution that has the permission of the minister of finance as a forum for the Public Accountant in carrying out its work. KAP incorporated into Big 4 has a tendency to report its financial statements more quickly, the reason is that the KAP has a good reputation so that it has good resources. Can be assessed in the following way:

Table 1: Dummy Size of Public Accounting Firm (KAP)

\begin{tabular}{cc}
\hline KAP & Dummy \\
\hline Partnering with Big Four & 1 \\
Not Partnering with Big Four & 0 \\
\hline
\end{tabular}

\section{Result \& Discussion}

Sample selection method used in this research is using Slovin method. To use the method, the error tolerance limits must first be determined. The fault tolerance limit is expressed by the percentage value. The smaller the fault tolerance value, will indicate the more accurate sample data from the population taken. For example, research with a given error limit of 5\%, this makes the study has a precision accuracy of $95 \%$, and research with a $2 \%$ error tolerance limit, this study means having a $98 \%$ accuracy rate.

In this study the fault tolerance that researchers use for $5 \%$ with the same number of populations, the smaller the fault tolerance, the greater the number of samples required. Researchers use the population of financial statements of companies trading services and investment services listed on the BEI with the period 2014 to 2016. The data used in the study is a kind of secondary data. The techniques in collecting data is done by collecting, recording and reviewing data that has been collected in the form of financial statements. List of the population can be seen in table 2 . 
Table 2: List of Research Populations

\begin{tabular}{lc}
\hline \multicolumn{1}{c}{ Type of Populations } & Total \\
\hline Large trade sub-sector of production goods & 33 \\
The retail trade sub-sector & 22 \\
Restaurant, hotel and tourism sub-sector & 21 \\
Health sub-sector & 4 \\
Computer services sub-sector and its equipment & 6 \\
Sub-sector of investment company & 10 \\
Sub-sector of advertising, printing media & 14 \\
Other sub-sectors & 5 \\
Total Populasi & 115 \\
\hline
\end{tabular}

Source: Secondary data is processed, 2017

To determine the processed sample, using the proportional strata method then taken randomly in accordance with the proportion that is balanced against the population taken, in table 3 is a table determining the number of samples.

Table 3: Determination of the number of samples

\begin{tabular}{cccccc}
\hline $\mathrm{N}$ & $\mathrm{N}_{\mathrm{n}}$ & $\mathrm{n}$ & $\%$ & \multicolumn{2}{c}{ Strata } \\
\hline 115 & 33 & 89 & 29 & 25.5 & 26 \\
115 & 22 & 89 & 19 & 17.0 & 17 \\
115 & 21 & 89 & 18 & 16.3 & 16 \\
115 & 4 & 89 & 3 & 3.1 & 3 \\
115 & 6 & 89 & 5 & 4.6 & 5 \\
115 & 10 & 89 & 9 & 7.7 & 8 \\
115 & 14 & 89 & 12 & 10.8 & 11 \\
115 & 5 & 89 & 4 & 3.9 & 4 \\
& 115 & & 100 & & 89 \\
\hline
\end{tabular}

For the variables used in the research, the variables are timeliness as the dependent variable, firm size, and public accounting firm (KAP) as independent variables. Table 4 lists the proportion of samples per sub-sector.

Table 4: List of Sample Proportion

\begin{tabular}{lccc}
\hline \multicolumn{1}{c}{ Sub Sector } & Total & Proportion & Number of Samples \\
\hline Large trade sub-sector of production goods & 33 & $29 \%$ & 26 \\
The retail trade sub-sector & 22 & $19 \%$ & 17 \\
Restaurant, hotel and tourism sub-sector & 21 & $18 \%$ & 16 \\
Health sub-sector & 4 & $3 \%$ & 3 \\
Computer services sub-sector and its equipment & 6 & $5 \%$ & 5 \\
Sub-sector of investment company & 10 & $9 \%$ & 8 \\
Sub-sector of advertising, printing media & 14 & $12 \%$ & 11 \\
Other sub-sectors & 5 & $4 \%$ & 4 \\
Total & 115 & $100 \%$ & 89 \\
\hline
\end{tabular}

Table 5: List of variable value of research

\begin{tabular}{lcccc}
\hline Research Variable & Min & Max & Mean & Std. Deviation \\
Timeliness & 42 & 138 & 79.70 & 13.887 \\
Company Size & .02 & 82851.68 & 6972.3 & 14351.4 \\
$\left(\mathrm{X}_{1}\right)$ & & & & \\
KAP $\left(\mathrm{X}_{2}\right)$ & 0.0 & 1 & 0.37 & .486 \\
Valid N (listwise) & & & & \\
\hline
\end{tabular}


Table 5 describes the mean of 6972.3 meaning that the whole value of the average firm size has a value of $\operatorname{Rp} 6972.3234$ billion. Standard deviation on firm size is 14351.4. The minimum value of 0.02 means that the entire value of the company's size is the lowest value of 0.02 billion. Maximum value of 82851.68 means that the entire value of the company's size listed on the Indonesia Stock Exchange as the research sample has the largest value of $\mathrm{Rp}$ 82851.68 billion. KAP Size shows a mean of 0.37 meaning that the whole value of the average KAP size has a value of 0.37 .

KAP standard deviation of 0.486 . The minimum value of 0.00 means that all of the lowest KAP size values are 0.00 . The maximum value of 1.00 means all KAP sizes listed on the IDX, which are sampled in the study has the largest value of 1.00. Timeliness has a mean of 79.70, meaning that the whole value of average timeliness has a value of 79 to 80 days. The standard deviation on the timeliness of 13,887 . The standard deviation is used to assess the average dispersion of the samples, thereby means the average spread of samples about timeliness by 14 days. A minimum value of 42 means all of the lowest value timeliness value of 42 days. The maximum value of 138, meaning that the entire timeliness value listed on the Indonesia Stock Exchange as the research sample has the greatest value of 138 days.

Table 6 illustrates the normality of the data concluded that the data in the regression model is normally distributed.

Table 6: One-Sample Kolmogorov-Smirnov Test

\begin{tabular}{llr}
\hline & & $\begin{array}{c}\text { Unstandardized } \\
\text { Residual }\end{array}$ \\
\hline $\mathrm{N}$ & & 89 \\
Normal Parameters & & .0000000 \\
& Mean & 13.29351847 \\
Most Extreme Differences & Std. Deviation & .072 \\
& Absolute & .072 \\
& Positive & -.071 \\
Test Statistic & Negative & .072 \\
Asymp. Sig. (2-tailed) & & $.200^{\mathrm{c}, \mathrm{d}}$ \\
\hline
\end{tabular}

To test whether there is autocorrelation in this research data conducted by using DurbinWatson test (DW) can be seen in table 7.

Table 7: The Summary ${ }^{\mathrm{b}}$

\begin{tabular}{cccccc}
\hline $\begin{array}{c}\text { Mode } \\
1\end{array}$ & $\mathrm{R}$ & $\begin{array}{c}\mathrm{R} \\
\text { Square }\end{array}$ & $\begin{array}{c}\text { Adjusted } \\
\text { R Square }\end{array}$ & $\begin{array}{c}\text { Std. Error of the } \\
\text { Estimate }\end{array}$ & $\begin{array}{c}\text { Durbin- } \\
\text { Watson }\end{array}$ \\
\hline 1 & $.289^{\mathrm{a}}$ & .084 & .028 & 13.68807 & 2.064 \\
\hline
\end{tabular}

To know the influence of company size and public accountant firm to timeliness used Multiple Linear regression. The results of the effect analysis can be seen in table 8 .

Table 8: Results of multiple linear regression analysis

\begin{tabular}{lcccccc}
\hline \multicolumn{1}{c}{ Model } & \multicolumn{2}{c}{ Unstandardized Coefficients } & Standardized Coefficients & T & Sig \\
& $\mathrm{B}$ & Std. Error & & & & \\
\hline 1 (Constant) & 70.484 & 26.170 & & 2.693 & .009 \\
Company & 7.130 & 17.302 & .048 & .412 & .681 \\
Size $\left(\mathrm{X}_{1}\right)$ & -.942 & 3.258 & -.033 & -.289 & .773 \\
KAP $\left(\mathrm{X}_{2}\right)$ & & & & \\
\hline
\end{tabular}


Based on table 8 , the decision making obtained the result that the firm size variable in the partial test using t-test is obtained, the size of the company has t-test 0.412 . the value is smaller than t-table of 1.989 , so that $0.412<1.989$ and stated the size of the company does not affect the timeliness. Based on the significant value of 0.681 greater than the 0.05 significance level indicates $0.681>0.05$ that firm size does not affect the timeliness. For KAP size variable, partial test using t-test is obtained that, KAP size has t-test -0.289 . The value is smaller than t-table of -1.989 , so $-0.289<-1.989$ and can be expressed KAP size does not affect the timeliness. Based on the significant value of 0.773 greater than the 0.05 significance level indicates $0.773>0.05$ that KAP size has no significant effect on timeliness.

\section{Conclusion}

1. Variable size of the company and public accountant office affect the timeliness of financial statement.

2. The information contained in a financial report, whether it can be good news or Bad News for investors, but information must be submitted on time so that investors can take an appropriate decision when needed.

3. From the results of multiple linear regression testing found under firm, size has no effect on timeliness. But in its implementation, company size can affect timeliness. This is because of the greater the value of corporate assets the timeliness in the delivery of financial reporting the better.

4. The size of the public accounting firm can affect the timeliness. The quality of KAP is determined by the professionalism, independence, and integrity of the KAP auditor.

\section{Reference}

[1] Z. F. Panjaitan and L. Amanah, "FAKTOR-FAKTOR YANG MEMPENGARUHI AUDIT DELAY DAN TIMELINESS ATAS PENYAMPAIAN LAPORAN KEUANGAN,” J. Ilmu Ris. Akunt. Vol., vol. 2, no. 11, pp. 1-18, 2013.

[2] L. S. Pratama and Haryanto, "PENGARUH FAKTOR INTERNAL DAN EKSTERNAL PERUSAHAAN TERHADAP TIMELINESS LAPORAN KEUANGAN," DIPONEGORO $\mathrm{J}$. Account., vol. 3, no. 2, pp. 1-12, 2014.

[3] S. Rachmawi, Rini, and Y. Fitri, "Faktor-Faktor Yang Mempengaruhi ketepatan Waktu pelaporan Keuangan Pemerintah Daerah Di Indonesia,” J. Ilmu Akunt., vol. 9, no. April, pp. 143$160,2016$.

[4] K. Alkhatib and Q. Marji, "Audit Reports Timeliness: Empirical Evidence from Jordan," Procedia - Soc. Behav. Sci., vol. 62, no. September, pp. 1342-1349, 2012.

[5] M. Ahmad, H. Mohamed, and S. P. Nelson, "The Association between Industry Specialist Auditor and Financial Reporting Timeliness - Post MFRS Period," Procedia - Soc. Behav. Sci., vol. 219, pp. 55-62, 2016.

[6] B. Vuran and B. Adiloglu, "Is Timeliness of Corporate Financial Reporting Related to Accounting Variables? Evidence From Istanbul Stock Exchange," Int. J. Bus. Soc. Sci., vol. 4, no. 6, pp. 58-70, 2013.

[7] H. Tugiman, Standar Profesional Audit Internal. Yogyakarta: Kanisius, 1997.

[8] S. Agoes, Auditing, 4th ed. Jakarta: Salemba Empat, 2013.

[9] R. R. Sari and I. Ghozali, "Faktor-Faktor Pengaruh Audit Report Lag," Diponegoro J. Account., vol. 3, no. 2, 2014.

[10] Sugiyono, Metode Penelitian. Jakarta: Rajawali Pers, 2014. 